\title{
Adiponectin as a Predictor for the Severity of Sepsis in ICU Patients
}

\author{
Mohammed Amin Abd-Elghany', Nahed Salah Eldin², Sherif Wadie', \\ Mervat Mohammed El Damarawy ${ }^{1}$, Fady Adib Abd-El-malek², Ashraf Abd El-Khalik Barakat ${ }^{1}$ \\ ${ }^{1}$ Intensive Care Medicine Department, Theodor Bilharz Research Institute, Cairo, Egypt \\ ${ }^{2}$ Anesthesia and Intensive Care Medicine Department, Ain Shams University, Cairo, Egypt
}

Email address:

Dr_mfalcon@hotmail.com (M. A. Abd-Elghany),h_damarawy@yahoo.com (M. M. El- Damarawy), fady-adib@yahoo.com (F. A. Abd-El-malek),dr.ashraf.a@hotmail.com (A. A. El-Khalik Barakat)

\section{To cite this article:}

Mohammed Amin Abd-Elghany, Nahed Salah Eldin, Sherif Wadie, Mervat Mohammed El Damarawy, Fady Adib Abd-El-malek, Ashraf Abd El-Khalik Barakat. Adiponectin as a Predictor for the Severity of Sepsis in ICU Patients. American Journal of Internal Medicine.

Vol. 3, No. 1, 2015, pp. 6-14. doi: 10.11648/j.ajim.20150301.12

\begin{abstract}
Sepsis is widely diagnosed In ICU patients. The sepsis markers are numerous with variable sensitivity and specificity. Adiponectin is a protein hormone that is secreted from adipose tissue into the bloodstream. It is a key substance in metabolic syndrome and has an anti-inflammatory property. The relationship between adiponectin and sepsis is unclear. In the current study, we aim to demonstrate that low plasma adiponectin level could be an early predictor for morbidity and mortality of sepsis by its comparison with c-reactive protein, serum lactate and procalcitonine. Thirty patients admitted to the intensive care unit with picture clinically suggesting sepsis were enrolled in the study. Predisposition, insult/infection, response, and organ dysfunction (PIRO) score was used to follow the course of the septic process. Plasma adiponectin level, serum lactate level, procalcitonin level(PCT), c-reactive protein(CRP) were checked on dayl then day 4 then day 7 and so on until ICU discharge or demise for a total of 28 days . PIRO score was able to expect sepsis prognosis with high statistical significance. Procalcitonin, serum lactate and adiponectin were valuable in follow up the sepsis prognosis with $\mathrm{P}$ value $(0,0.01 \& 0$ respectively) on the contrary CRP had poor prognostic value in sepsis follow up (P value 0.16 ). We conclude that PIRO score is an effective model for staging of sepsis and predict mortality. Measuring serial procalcitonin levels may be the most useful in order to understand the trend, identify the peak, and be able to identify resolution of sepsis. Early high lactate level is a predictor for poor prognosis of sepsis. Adiponectin is similar to procalcitinin in early detection of sepsis \& can be used as a prognostic indicator with considering that adiponectin level could be affected by other metabolic disorders.
\end{abstract}

Keywords: Sepsis, Sepsis Markers, PIRO Score, Adiponectin

\section{Introduction}

Approximately $40 \%$ of all intensive care unit patients have sepsis on admission to the intensive care unit or experience sepsis during their stay in the intensive care unit [1]. Crude in-hospital mortality rates ranged from $16.9 \%$ in uninfected patients to $53.6 \%$ in patients who were infected [2].

Systemic inflammatory response syndrome (SIRS), sepsis, severe sepsis, and septic shock were initially defined by the American College of Chest Physicians (ACCP) and Society of Critical Care Medicine (SCCM) [3]. These definitions were reconsidered in 2001 during an International Sepsis Definitions Conference [4]. A practical modification of the definitions has since been published, which provides exact hemodynamic definitions for septic shock [5].

Systemic inflammatory response syndrome is the clinical syndrome that results from a dysregulated inflammatory response to a noninfectious insult. It requires that two or more of the following abnormalities be present, temperature $>38.3^{\circ} \mathrm{C}$ or $<36^{\circ} \mathrm{C}$, heart rate $>90$ beats $/ \mathrm{min}$, respiratory rate $>20$ breaths $/ \mathrm{min}$ or $\mathrm{PaCO} 2<32 \mathrm{mmHg}$, WBC $>12,000$ cells $/ \mathrm{mm} 3,<4000$ cells $/ \mathrm{mm} 3$, or $>10$ percent immature (band) forms. Sepsis is the clinical syndrome that results from a dysregulated inflammatory response to an infection. Severe sepsis refers to sepsis plus at least one of the signs of hypoperfusion or organ dysfunction. Septic shock 
exists if there is severe sepsis plus one or both of the following, systemic mean blood pressure is $<60 \mathrm{mmHg}$ despite adequate fluid resuscitation and maintaining the systemic mean blood pressure $>60 \mathrm{mmHg}$ requires dopamine $>5 \mathrm{mcg} / \mathrm{kg}$ per $\mathrm{min}$, norepinephrine $>0.25 \mathrm{mcg} / \mathrm{kg}$ per min, or epinephrine $>0.25$ $\mathrm{mcg} / \mathrm{kg}$ per min despite adequate fluid resuscitation [6].

A number of risk factors exist for the development and progression of sepsis, including advanced age, compromised immune system response, chronic illness, broad-spectrum antibiotic use, and exposure to infection risk associated with surgical and invasive procedures [7].

Many believe that sepsis develops as a result of exuberant production of proinflammatory molecules, lysosomal enzymes, superoxide-derived free radicals, vasoactive substances, such as platelet-activating factor (PAF), tissue factor (TF), and plasminogen activator inhibitor-1 (PAI-1) [8]. This occurs in conjunction with increases in the expression of inducible nitric oxide (NO) synthase, increasing production of NO resulting in coagulopathy, endothelial dysfunction, vascular instability, and eventually to apoptosis (i.e. programmed cell death) and multi-organ failure [8].

A marker of sepsis has been defined as a measure that predicts the presence or severity of the disease. To be a useful, the substance being measured must rise above normal levels early in the course of the infectious process [9].

Sepsis biomarkers have included procalcitonin (PCT) [10], various interleukins (ILs) [10], eosinophil count [11], adrenomedullin (ADM) and pro-ADM [12], atrial natriuretic peptide (ANP) and pro-ANP, [13], pro-vasopressin (copeptin) [12], interferon- $\gamma$ (IFN- $\gamma$ ) [14], triggering receptor expressed on myeloid cells 1 (TREM-1) [14], resistin [15] and CD64 expression on the neutrophil membrane [16\&17].

C-Reactive Protein (CRP) is acute-phase protein released by the liver after the onset of inflammation or tissue damage. Some studies showed the value of CRP as a marker of sepsis [18] and other studies showed a limited value of CRP as a marker of sepsis [19].

Procalcitonin PCT has been studied as a possible marker of sepsis with a superior sensitivity and specificity [20] and, in some countries, is now being included in routine clinical practice and guideline recommendations [21]. PCT is a propeptide of calcitonin and is normally produced in the C-cells of the thyroid gland and the normal PCT levels are very low $(<0.2 \mathrm{ng} / \mathrm{ml})$. During sepsis, PCT is produced by extrathyroid tissues (monocytes, liver) resulting in high levels [22\&23].

The normal blood lactate concentration in unstressed patients is $0.5-1 \mathrm{mmol} / \mathrm{L}$. Hyperlactatemia is defined by lactate concentrations above $2 \mathrm{mmol} / \mathrm{L}$ and in patients with septic shock lactate levels are more than $(5 \mathrm{mmol} / \mathrm{L})$ [24]. A single venous lactate measurement above $4 \mathrm{mmol} / \mathrm{l}$ predicted short-term and in-hospital risk for death in patients with suspected infection [25].

Adiponectin is an anti-inflammatory adipokine secreted by adipose tissue. Its deficiency is associated with increased mortality and morbidity in septic patients [26\& 27]. Adiponectin contains 247 amino acids. The circulating plasma range of adiponectin in human subjects is $3-30 \mu \mathrm{g} / \mathrm{mL}$ [28]. The secretion of adiponectin by adipocytes appears to be hormone regulated [29]. Compared to other adipokines such as leptin and resistin, both considered being proinflammatory [30\&31].

Adiponectin deficiency may cause the severe systemic inflammatory response and high mortality [32]. The degree of decreasing plasma adiponectin levels during sepsis might depend on the insult severity. It has been reported that recombinant adiponectin improved mortality in sepsis [33].

The aim of our study is to demonstrate that low plasma adiponectin level could be an early predictor for morbidity and mortality of sepsis by its comparison with CRP, serum lactate and procalcitonin levels.

\section{Patients and Methods}

The study involved thirty patients admitted to the ICU with picture suggesting sepsis. Inclusion criteria, age $\geq 19$ years [below this age group the adiponectin levels are not stable in relation to body fat cells], body mass index (BMI) equals or more than $25 \mathrm{~kg} / \mathrm{m}^{2}$, informed consent given by the patient or first degree relative and sepsis criteria, [clinically suspected infection confirmed infection and 2 or more of the following; Temperature $>38^{\circ} \mathrm{C}$ or $<36^{\circ} \mathrm{C}$, heart rate $(\mathrm{HR})>90 / \mathrm{min}$, Respiratory rate $(\mathrm{RR})>20 / \mathrm{min}$ or $\mathrm{PaCO} 2<32 \mathrm{mmHg}$, White blood cell count $>12,000 / \mathrm{mm}^{3}$ or $\left.<4000 / \mathrm{m}^{3}\right]$. Exclusion criteria, age $<19$ years, BMI $<25 \mathrm{~kg} / \mathrm{m}^{2}$, chronic renal failure [adiponectin level is double fold elevated in chronic renal failure].

Each was subjected to; detailed history, physical examination and laboratory investigations (CBC, serum creatinine, urea, AST, ALT, total proteins, albumin, total bilirubin, coagulation profile and ABGs). These routine laboratories investigations were withdrawn on study day 1 and subsequently thereafter every day until ICU discharge or demise. Specific laboratory investigations include plasma adiponectin level, serum lactate level, procalcitonin level (PCT) and C-reactive protein (CRP). These specific Labs were done on day1, day 4, day 7 and so on until ICU discharge or demise for a total of 28 days.

Microbiological studies included pan cultures (sputum, blood, urine or biological fluid) and imaging studies were done to identify the source of sepsis.

Clinical data; length of ICU stay, final outcome and need for organ supportive measures (vasopressors, mechanical ventilation and/or hemodialysis) were reported for all patients until ICU discharge or demise.

Scoring system; Predisposition, insult/infection, response and organ dysfunction (PIRO) score is an effective model for staging of sepsis and seems to be predictive of mortality. 
Table (1). variants and scoring parameters on which PIRO score depends.

\begin{tabular}{|c|c|c|c|c|c|}
\hline $\begin{array}{l}\text { Predis- } \\
\text { position }\end{array}$ & P0: Age_46 yrs & $\begin{array}{l}\text { P1: Age 46-64 yrs, } \\
\text { no CLD }\end{array}$ & $\begin{array}{l}\text { P2: Age 64-85 yrs, no CLD } \\
\text { and no congestive } \\
\text { cardiomyopathy }\end{array}$ & $\begin{array}{l}\text { P3: Age 46-64 yrs with CLD or } \\
\text { 64-85 yrs with Congestive } \\
\text { cardiomyopathy }\end{array}$ & $\begin{array}{l}\text { P4: Age 64-85 yrs } \\
\text { with CLD or age } \\
\text { _85 yrs }\end{array}$ \\
\hline $\begin{array}{l}\text { Insult/ } \\
\text { infection }\end{array}$ & $\begin{array}{l}\text { I0: CA-UTI } \\
\text { Gramnegative }\end{array}$ & $\begin{array}{l}\text { I1: CA-UTI not } \\
\text { Gramnegative }\end{array}$ & $\begin{array}{l}\text { I2: CA infection except } \\
\text { CA-UTI or nosocomial } \\
\text { Grampositive }\end{array}$ & $\begin{array}{l}\text { I3: Nosocomial acquired infection } \\
\text { except Gram-positive or nosocomial } \\
\text { fungal nonabdominal infection }\end{array}$ & $\begin{array}{l}\text { I4: Nosocomial } \\
\text { abdominal fungal } \\
\text { infection }\end{array}$ \\
\hline Response & $\begin{array}{l}\text { R0: No } \\
\text { tachycardia and/or } \\
\text { no tachypnea }\end{array}$ & $\begin{array}{l}\text { R1: Both } \\
\text { tachycardia and } \\
\text { Tachypnea }\end{array}$ & & & \\
\hline $\begin{array}{l}\text { Organ } \\
\text { dysfunction }\end{array}$ & O0: $2 \mathrm{OF}$ & O1: 3 OF, 1 hepatic & $\mathrm{O} 2: 3 \mathrm{OF}$, none hepatic & $\mathrm{O} 3: 4 \mathrm{OF}$ & O4: 5 OF \\
\hline
\end{tabular}

CLD, chronic liver disease; CA-UTI, community-acquired urinary tract infections; OF, organ failures.

PIRO gives the patient scale from $0-13$ according to the parameters explained in the table and the higher the scale the more the morbidity and mortality from the septic process. The data collected was tabulated and statistically analyzed.

Statistical methods:

IBM SPSS statistics (V. 20.0, IBM Corp., USA, 2011) was used for data analysis. Data were expressed as the mean \pm standard deviation (SD) for numerical variables. $\mathrm{P} \leq 0.05$ was considered to be statistically significant and $\mathrm{P}<0.01$ considered being highly statistically significant.

\section{Results}

The study involved thirty patients admitted to the ICU with picture suggesting sepsis. Fifteen from the included patients were discharged safely from the ICU while fifteen died.

Table (2). Demographic data of the cases ( $n=30): *$.

\begin{tabular}{llllll}
\hline & N & Min & Max & Mean & SD \\
\hline Age $($ years $)$ & 30 & 29 & 97 & 65.33 & 14.528 \\
Weight $(\mathrm{Kg})$ & 30 & 58 & 160 & 93.1 & 18.578 \\
Height $(\mathrm{m})$ & 30 & 151 & 178 & 164.67 & 9.36 \\
BMI $\left(\mathrm{Kg} / \mathrm{m}^{2}\right)$ & 30 & 29.1 & 62.5 & 35.47883 & 7.222227 \\
\hline
\end{tabular}

Table (3). Comparison between discharged and died patients as regards $B W$, $H t \& B M I^{*}$

\begin{tabular}{llllllll}
\hline & Out-Come & N & Mean & SD & T & P & Sig. \\
\hline \multirow{2}{*}{ BW } & Disch. & 15 & 85.53 & 22.196 & & & \\
& Died & 15 & 100.67 & 9.978 & 2.408 & 0.026 & S \\
\multirow{2}{*}{$\mathrm{Ht}$} & Disch. & 15 & 165.53 & 9.613 & & & \\
& Died & 15 & 163.8 & 9.352 & 0.501 & 0.621 & NS \\
\multirow{2}{*}{ BMI } & Disch. & 15 & 33.2167 & 8.785592 & & & \\
& Died & 15 & 37.745 & 4.45596 & 1.782 & 0.089 & NS \\
\hline
\end{tabular}

*Independent $\mathrm{t}$ test. * Data are presented as mean \pm standard deviation. BW: body weight, Ht: height, BMI: body mass index

There was positive correlation between the mortality versus the body weight with P-value (0.026), while no significant correlation was detected versus the height or the BMI.
Table (4). Sex Outcome Cross tabulation:*

\begin{tabular}{|c|c|c|c|c|}
\hline & & \multicolumn{2}{|c|}{ Outcome } & \multirow[t]{2}{*}{ Total } \\
\hline & & Disch. & Died & \\
\hline \multirow[t]{2}{*}{ Female } & Count & 6 & 5 & 11 \\
\hline & $\%$ within Outcome & $40.0 \%$ & $33.3 \%$ & $36.7 \%$ \\
\hline \multirow[t]{2}{*}{ Male } & Count & 9 & 10 & 19 \\
\hline & $\%$ within Outcome & $60.0 \%$ & $66.7 \%$ & $63.3 \%$ \\
\hline \multirow[t]{2}{*}{ Total } & Count & 15 & 15 & 30 \\
\hline & $\%$ within Outcome & $100.0 \%$ & $\begin{array}{l}100.0 \\
\%\end{array}$ & $100.0 \%$ \\
\hline \multicolumn{5}{|c|}{ Chi-Square Tests } \\
\hline & & Value & $\mathrm{P}$ & \\
\hline \multicolumn{2}{|c|}{ Pearson Chi-Square } & $.144 \mathrm{a}$ & .705 & \\
\hline
\end{tabular}

It was found that the gender had no significant relation to the outcome.

Table (5). Correlations between adiponectin $(\mu g / L)$ versus other variables in cases $(n=30)$ : *

\begin{tabular}{llllll}
\hline & & Age & Wt & Ht & BMI \\
\hline \multirow{3}{*}{ Adiponectin_dC } & R & -0.31 & -0.394 & 0.141 & 0.24 \\
& P & 0.095 & 0.031 & 0.459 & 0.201 \\
& Sig. & NS & S & NS & NS \\
\hline
\end{tabular}

$* \mathrm{dC}=$ delta change: for correlation with other variables

There was negative correlation between adiponectin $(\mu \mathrm{g} / \mathrm{L})$ versus BW with P-value 0.031 .

Table (6). Correlations between adiponectin ( $\mu g / L), \quad C R P$ (mg/L), Procalcitonin $(\mu \mathrm{g} / \mathrm{L})$, Lactate $(\mathrm{mmol} / \mathrm{L})$ versus PIRO score in cases $(n=30)$ : *.

\begin{tabular}{|c|c|c|}
\hline & & PIRO_dC \\
\hline \multirow{3}{*}{ CRP_dC } & $\mathrm{R}$ & 0.121 \\
\hline & $\mathrm{P}$ & 0.525 \\
\hline & Sig. & NS \\
\hline \multirow{3}{*}{ Procal_dC } & $\mathrm{R}$ & 0.672 \\
\hline & $\mathrm{P}$ & 0 \\
\hline & Sig. & HS \\
\hline \multirow{3}{*}{ Lact_dC } & $\mathrm{R}$ & 0.434 \\
\hline & $\mathrm{P}$ & 0.016 \\
\hline & Sig. & $\mathrm{S}$ \\
\hline \multirow{3}{*}{ Adipo_dC } & $\mathrm{R}$ & -0.524 \\
\hline & $\mathrm{P}$ & 0.003 \\
\hline & Sig. & HS \\
\hline
\end{tabular}

$* \mathrm{dC}=$ delta change $:$ for correlation with other variables

There was negative correlation between adiponectin $(\mu \mathrm{g} / \mathrm{L})$ versus PIRO score with highly significant P-value 0.003 . There was positive correlation between prcalcitonin $(\mu \mathrm{g} / \mathrm{L})$ 
versus PIRO score with significant P-value 0.

There was positive correlation between lactate $(\mathrm{mmol} / \mathrm{L})$ versus PIRO score with highly significant P-value 0.016 .
While no significant correlation was detected between $\mathrm{CRP}(\mathrm{mg} / \mathrm{L})$ versus PIRO score.

Table (7). Prognostic value of PIRO score.

\begin{tabular}{|c|c|c|c|c|c|c|c|c|c|c|}
\hline & $\begin{array}{l}\text { PIRO_S } \\
\text { c_day } 1\end{array}$ & $\begin{array}{l}\text { PIRO_S } \\
\text { c_day } 4\end{array}$ & $\begin{array}{l}\text { PIRO_Sc } \\
\text { day } 7\end{array}$ & $\begin{array}{l}\text { PIRO_Sc } \\
\text { day } 10\end{array}$ & $\begin{array}{l}\text { PIRO_Sc } \\
\text { day } 13\end{array}$ & $\begin{array}{l}\text { PIRO_Sc } \\
\text { day } 17\end{array}$ & $\begin{array}{l}\text { PIRO_Sc_ } \\
\text { day } 20\end{array}$ & $\begin{array}{l}\text { PIRO_Sc } \\
\text { day } 23\end{array}$ & $\begin{array}{l}\text { PIRO_Sc_ } \\
\text { day } 27\end{array}$ & $\begin{array}{l}\text { PIRO_ } \\
\text { dC }\end{array}$ \\
\hline Z & -1.888 & -3.333 & -3.559 & -3.298 & -0.748 & -1.528 & -1.557 & -1.528 & -0.748 & -3.054 \\
\hline P & 0.059 & 0.001 & 0 & 0.001 & 0.455 & 0.127 & 0.12 & 0.127 & 0.455 & 0.002 \\
\hline Sig. & NS & HS & HS & HS & NS & NS & NS & NS & NS & HS \\
\hline
\end{tabular}

* Wilcoxon Rank Sum Test

On comparing the values of PIRO score that were serially detected in all cases those who were discharged \& those who died the score was able to expect the prognosis with high statistical significance during days $4,7 \& 10$ with $\mathrm{P}$ values $0.001,0$ \& 0.001 respectively.

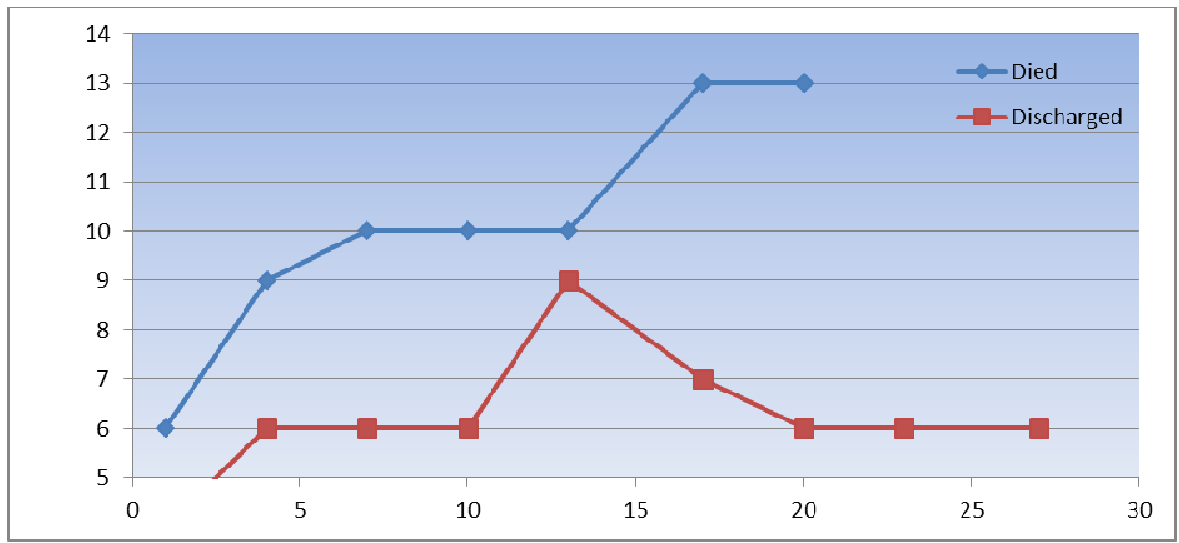

Figure (1). Follow-up chart to study PIRO score pattern among different times for both died discharged patients.

Table (8). Prognostic value of S. adiponectin $(\mu \mathrm{g} / L)$.

\begin{tabular}{lllllllllll}
\hline & $\begin{array}{l}\text { Adipo_ } \\
\text { day 1 }\end{array}$ & $\begin{array}{l}\text { Adipo_ } \\
\text { day 4 }\end{array}$ & $\begin{array}{l}\text { Adipo_ } \\
\text { day 7 }\end{array}$ & Adipo_day 10 & $\begin{array}{l}\text { Adipo_ } \\
\mathbf{1 3}\end{array}$ & $\begin{array}{l}\text { day } \\
\text { Adipo_- } \\
\text { day 17 }\end{array}$ & $\begin{array}{l}\text { Adipo_- } \\
\text { day 20 }\end{array}$ & $\begin{array}{l}\text { Adipo_day } \\
\text { 23 }\end{array}$ & $\begin{array}{l}\text { Adipo_- } \\
\text { day 27 }\end{array}$ & \multicolumn{1}{c}{ Adipo_dC } \\
\hline Z & -0.146 & -1.455 & -0.679 & -0.753 & -0.298 & -1.528 & -1.5 & -1.455 & -0.146 & -4.21 \\
P & 0.884 & 0.146 & 0.497 & 0.451 & 0.766 & 0.127 & 0.134 & 0.146 & 0.884 & 0 \\
Sig. & NS & NS & NS & NS & NS & NS & NS & NS & NS & HS \\
\hline
\end{tabular}

* Wilcoxon Rank Sum Test

On comparing the values of Adiponectin that were serially detected in all cases those who were discharged \& those who died The degree of change due to follow-up study (delta change or $\mathrm{dC}$ ) that reflects the actual different changes through the follow-up study was highly significant with P-value 0 .

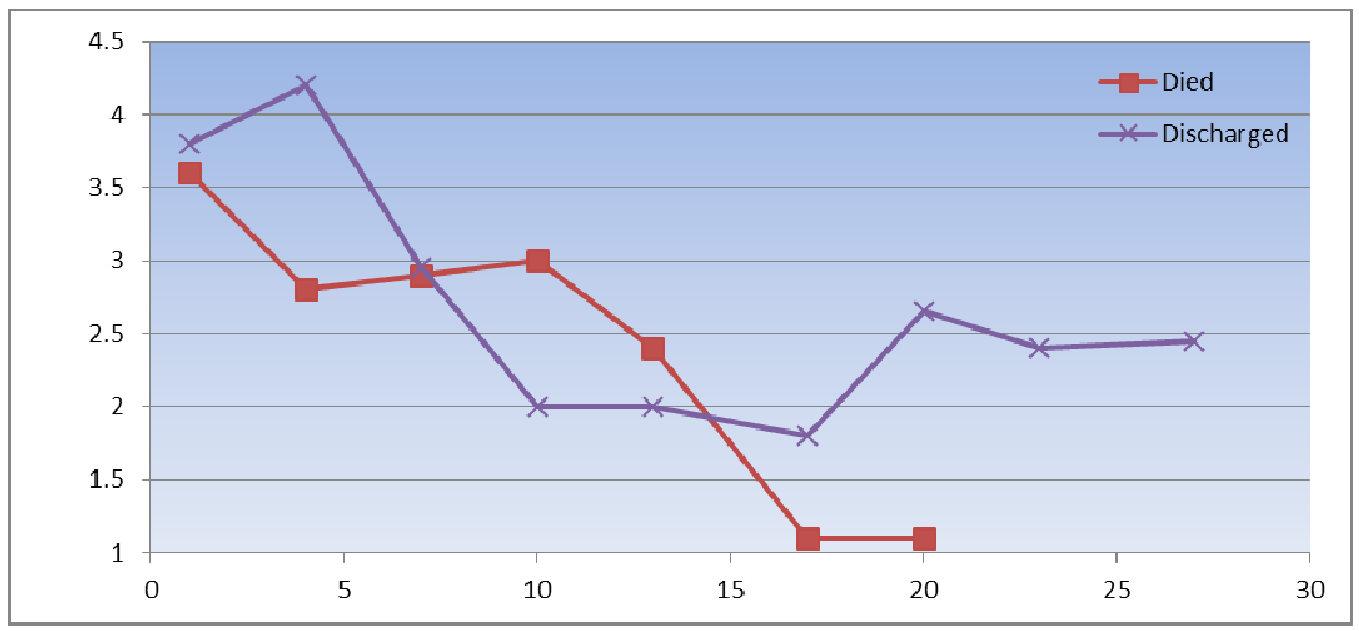

Figure (2). Follow-up chart to study Adipo. Pattern among different times for both died discharged patients. 
Table (9). Prognostic value of S. Procalcitonin $(\mu \mathrm{g} / L)$.

\begin{tabular}{lllllllllll}
\hline $\mathbf{Z}$ & $\begin{array}{l}\text { Procal_ } \\
\text { day 1 }\end{array}$ & $\begin{array}{l}\text { Procal_ } \\
\text { day 4 }\end{array}$ & $\begin{array}{l}\text { Procal_ } \\
\text { day } \mathbf{7}\end{array}$ & $\begin{array}{l}\text { Procal_day } \\
\mathbf{1 0}\end{array}$ & $\begin{array}{l}\text { Procal_day } \\
\mathbf{1 3}\end{array}$ & $\begin{array}{l}\text { Procal_ } \\
\text { day 17 }\end{array}$ & $\begin{array}{l}\text { Procal_- } \\
\text { day 20 }\end{array}$ & $\begin{array}{l}\text { Procal_- } \\
\text { day 23 }\end{array}$ & $\begin{array}{l}\text { Procal_- } \\
\text { day 27 }\end{array}$ & Procal_dC \\
\hline P & -0.062 & -1.742 & -1.57 & -0.883 & -0.293 & -1.514 & -1.5 & -1.514 & -1.57 & -3.588 \\
Sig. & 0.95 & 0.081 & 0.116 & 0.377 & 0.77 & 0.13 & 0.134 & 0.13 & 0.116 & 0 \\
& NS & NS & NS & NS & NS & NS & NS & NS & NS & HS \\
\hline
\end{tabular}

* Wilcoxon Rank Sum Test

On comparing the values of Procalcitonin that were serially detected in all cases those who were discharged \& those who died The degree of change due to follow-up study (delta change or $\mathrm{dC}$ ) that reflects the actual different changes through the follow-up study was highly significant with P-value 0 .

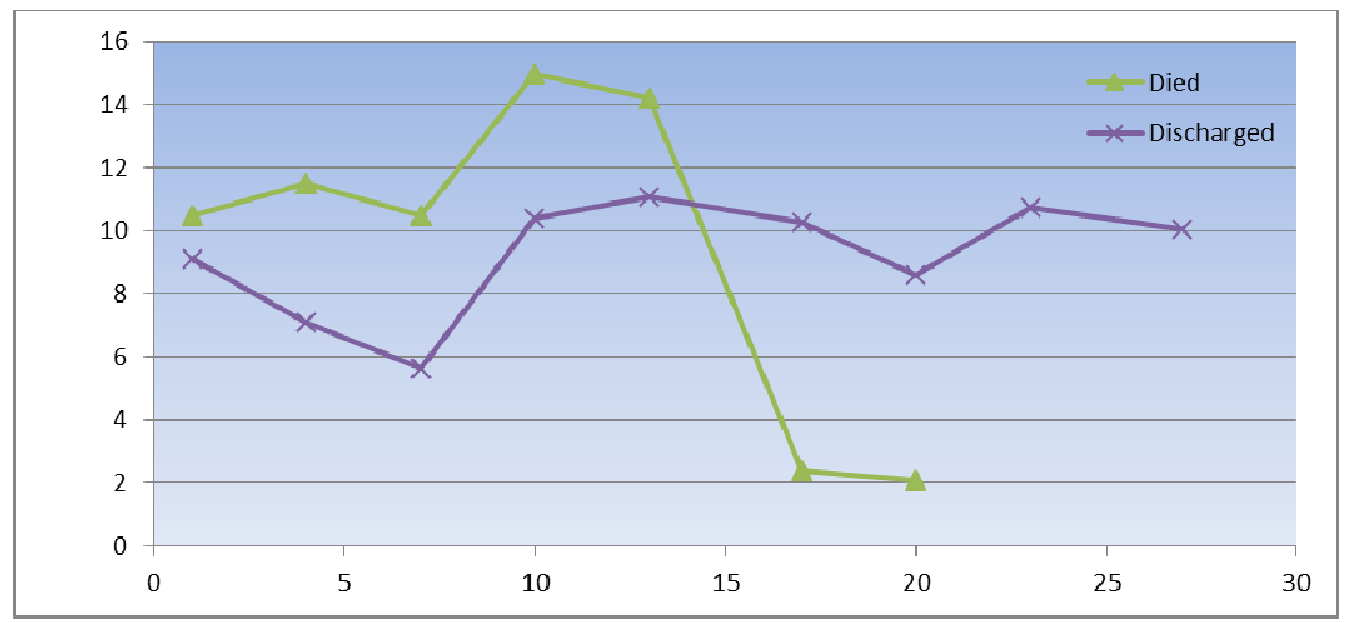

Figure (3). Follow-up chart to study Procal.pattern among different times for both died discharged patients.

Table (10). Prognostic value of S. Lactate (mmol/l).

\begin{tabular}{|c|c|c|c|c|c|c|c|c|c|c|}
\hline & $\begin{array}{l}\text { Lactate_ } \\
\text { day } 1\end{array}$ & $\begin{array}{l}\text { Lactate day } \\
\quad 4\end{array}$ & $\begin{array}{l}\text { Lactate_da } \\
\text { y7 }\end{array}$ & Lactate_day10 & $\begin{array}{l}\text { Lactate_day1 } \\
3\end{array}$ & $\begin{array}{l}\text { Lactate_d } \\
\text { ay17 }\end{array}$ & $\begin{array}{l}\text { Lactate } \\
\text { day } 20\end{array}$ & $\begin{array}{l}\text { Lactate } \\
\text { day } 23\end{array}$ & $\begin{array}{l}\text { Lactate } \\
\text { day } 27\end{array}$ & $\begin{array}{c}\text { Lact } \\
\text { dC }\end{array}$ \\
\hline Z & -2.009 & -3.433 & -3.352 & -3.19 & -1.794 & -0.509 & -0.757 & -2.009 & -2.009 & -2.554 \\
\hline$P$ & 0.045 & 0.001 & 0.001 & 0.001 & 0.073 & 0.611 & 0.449 & 0.045 & 0.045 & 0.011 \\
\hline Sig & $\mathrm{S}$ & HS & $\mathrm{HS}$ & HS & NS & NS & NS & $\mathrm{S}$ & $\mathrm{S}$ & S \\
\hline
\end{tabular}

* Wilcoxon Rank Sum Test

On comparing the values of Lactate that were serially detected in all cases those who were discharged \& those who died although the values detection serially had variable significance The degree of change due to follow-up study (delta change or $\mathrm{dC}$ ) that reflects the actual different changes through the follow-up study was significant with P-value 0.011 .

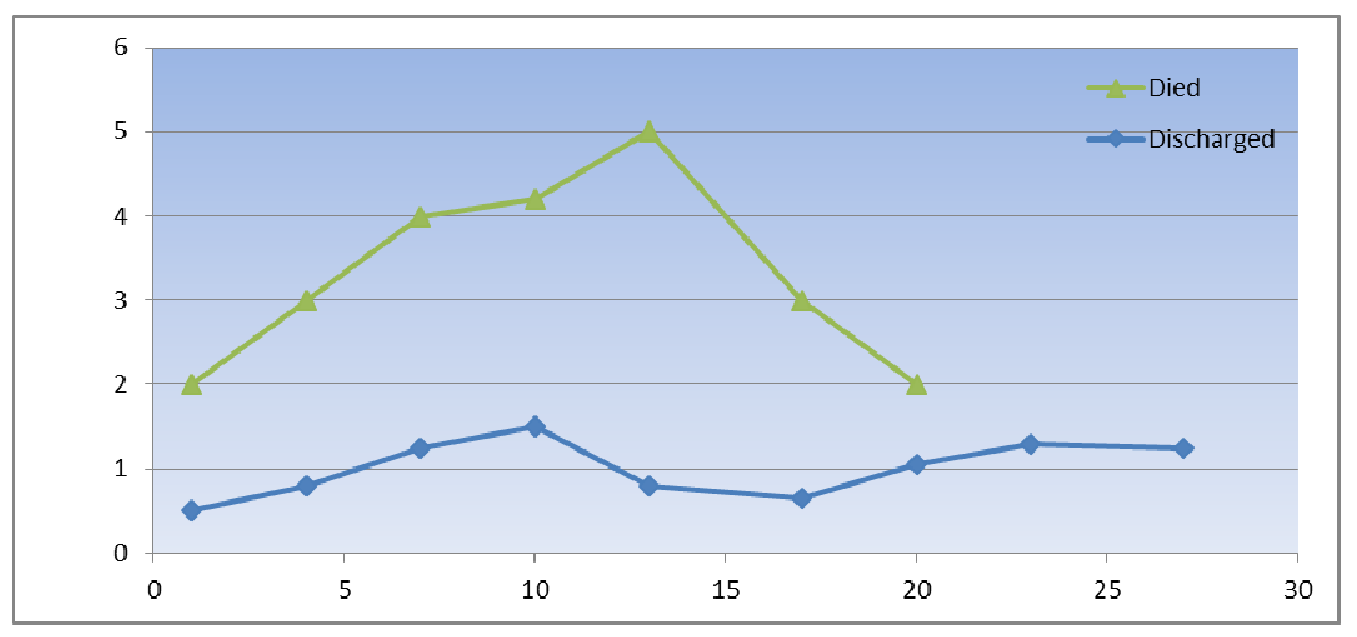

Figure (4). Follow-up chart to study Lactate pattern among different times for both died discharged patients. 
Table (11). Prognostic value of CRP (mg/dl).

\begin{tabular}{|c|c|c|c|c|c|c|c|c|c|c|}
\hline & CRP_day 1 & $\begin{array}{l}\text { CRP }_{-} \\
\text {day } 4\end{array}$ & $\begin{array}{l}\text { CRP_day }_{7} \\
\end{array}$ & $\begin{array}{l}\text { CRP } \\
\text { day } 10\end{array}$ & $\begin{array}{l}\text { CRP } \\
\text { day } 13\end{array}$ & $\begin{array}{l}\text { CRP }_{\overline{1}} \\
\text { day } 17\end{array}$ & $\begin{array}{l}\text { CRP } \\
\text { day } 20\end{array}$ & $\begin{array}{l}\text { CRP } \\
\text { day } 23\end{array}$ & $\begin{array}{l}\text { CRP } \\
\text { day } 27\end{array}$ & CRP_dC \\
\hline$Z$ & -0.291 & -1.639 & -0.246 & -0.132 & -0.588 & -1.514 & -1 & -0.132 & -0.588 & -1.39 \\
\hline P & 0.771 & 0.101 & 0.806 & 0.895 & 0.557 & 0.13 & 0.317 & 0.895 & 0.557 & 0.165 \\
\hline Sig. & NS & NS & NS & NS & NS & NS & NS & NS & NS & NS \\
\hline
\end{tabular}

CRP follow up has no significant correlation versus the prognosis of sepsis although it was high in most cases on

following the disease .

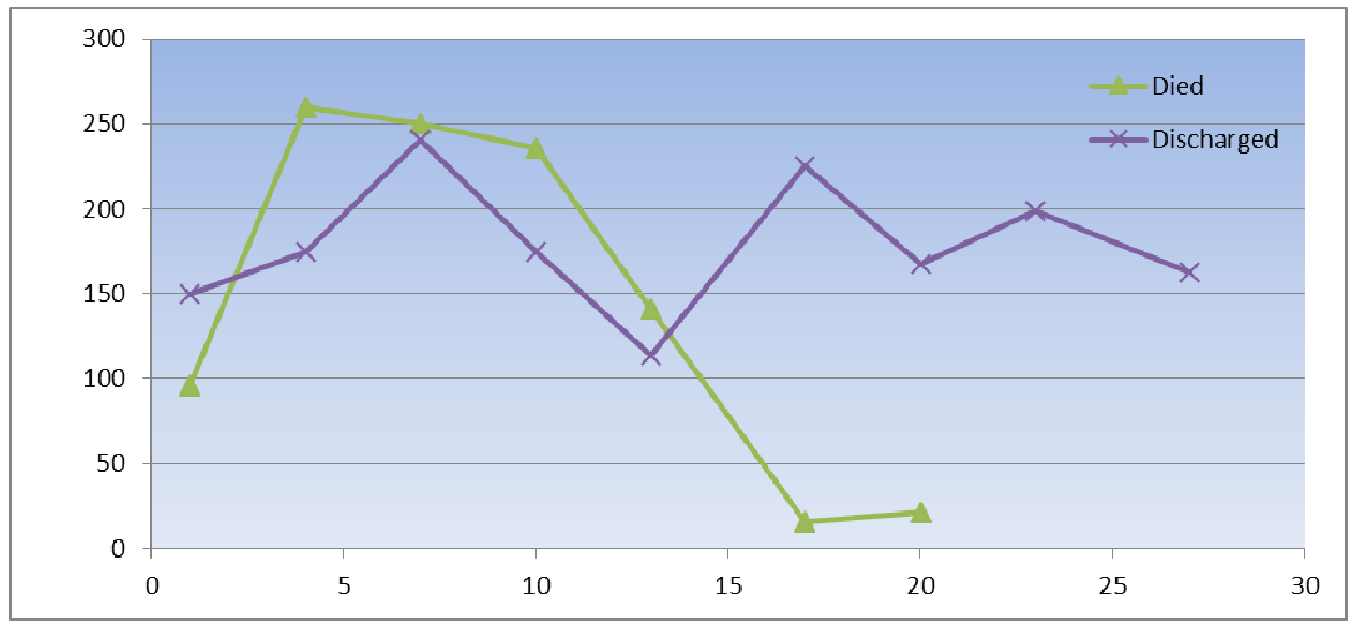

Figure (5). Follow-up chart to study CRP pattern among different times for both died discharged patients.

\section{Discussion}

Sepsis is the clinical syndrome that results from a dysregulated inflammatory response to an infection [6]. A marker of sepsis has been defined as a measure that predicts the presence or severity of the disease. Procalcitonin (PCT), in some countries, is now being included in routine clinical practice and guideline recommendations [21]. A single venous lactate measurement above $4 \mathrm{mmol} / \mathrm{l}$ predicted short-term and in-hospital risk for death in patients presenting at the emergency unit with suspected infection [25]. Adiponectin is an anti-inflammatory adipokine secreted by adipose tissue [34] and its deficiency is associated with increased mortality and morbidity in septic patients [26].

The current study that was conducted on 30 critically ill patients admitted to the Intensive Care unit with sepsis. 15 were discharged safely from ICU while 15 were died.

Mean body weight (BW) of patients who were died was $100.67 \mathrm{Kg}$ while it was $85.35 \mathrm{Kg}$ for those who were discharged giving positive correlation between the mortality versus the body weight with P-value (0.026), confirming the study of [26] which mentioned that obesity is associated with increased mortality and morbidity in septic patients.

In the current study there was negative correlation between adiponectin levels $(\mu \mathrm{g} / \mathrm{L})$ versus patients' BW with (P-value 0.031 ). This meets what was mentioned by [28] that obesity is considered a known adiponectin deficient state and another case-control study, in which confounding factors such as obesity were adjusted, significantly lower concentrations of circulating adiponectin were present in patients with obesity compared to those without [35].
Predisposition, insult/infection, response, and organ dysfunction (PIRO) score is an effective model for staging of sepsis and seems to be predictive of mortality [36]. Rello and his colleagues found that PIRO score performed well as 28-day mortality prediction tool in community acquired pneumonia patients requiring ICU admission [37]. Furtado and his colleagues on the other hand suggested that PIRO score was not a good predictor of intensive care unit mortality in their study [38]. While Orlando and Endaya, confirmed the validity and simplicity of PIRO score as a tool for assessing risk of severity for patients with sepsis in the ICU and may guide clinicians in managing patients. PIRO score was used in the current study to follow the course of the septic process in each patient with maximum 28 days, the score was able to expect the prognosis with high statistical significance during days $4,7 \& 10$ with $P$ values $0.001,0$ and 0.001 respectively [39].

Póvoa and his colleagues measured CRP daily after starting the antibiotic course for community acquired sepsis and found that it was useful as early as day 3 in identification of community acquired sepsis patients with poor outcome. The rate of CRP decline during the first five ICU days was markedly associated with prognosis [40]. While Gokmen and his colleagues demonstrated that CRP had low predictive value regarding gram positive and gram negative infection and isn't a good early marker for sepsis. In the current study we found CRP follow up had no significant correlation versus the prognosis of sepsis although it was high in most cases on following the disease [41].

The current study prospectively looked at every $72 \mathrm{hs}$ PCT measurements in patients with sepsis and correlated the results 
with prognosis guided by PIRO score during the ICU stay. On comparing the values of procalcitonin that were serially detected in all patients, the degree of change due to follow-up study (delta change or $\mathrm{dC}$ ) that reflects the actual different changes through the follow-up study was highly significant with P-value 0. These results are meeting with the results of both Giamarellos-Bourboulis and his colleagues and Jensen and his colleagues that PCT has an important value in follow up the prognosis of the septic process [42]\& [43] and thus supports the suggestion of Schuetz and his colleagues that PCT can be a guide for early use of antibiotics and also early discontinuation [44].

Regarding serum lactate when prospectively measured at every $72 \mathrm{hs}$ in patients with sepsis and correlated the results with their prognosis guided by PIRO score during the ICU stay we found that there was positive correlation between lactate (mmol/L) versus PIRO score with highly significant P-value 0.016. On comparing the values of Lactate that were serially detected in all patients, the values detected serially had variable significance with the higher significant values achieved on following the lactate on days $1,4,7$ and 10 . The degree of change due to follow-up study (delta change or $\mathrm{dC}$ ) that reflects the actual different changes through the follow-up study was significant with P-value 0.011. The results are with study published by Bakker and Jansen, showed that venous lactate predicted 28-day in-hospital mortality [45]. Nguyen and his colleagues observed the evolution of serial lactate levels in patients with severe sepsis during the first $6 \mathrm{~h}$ of treatment. In their study, a $10 \%$ decrease in lactate levels during the 6-h study period was related to an $11 \%$ decrease in the likelihood of mortality [46].

In the current study, there was negative correlation between adiponectin $(\mu \mathrm{g} / \mathrm{L})$ versus PIRO score with highly significant $\mathrm{P}$-value 0.003 meaning that the lower the adiponectin the more severe the sepsis. Teoh and his colleagues found that low adiponectin was associated with a heightened inflammatory response. So the authors suggested that low adiponectin may guide to a high risk for sepsis-related complications [33]. Van Meurs and his colleagues induced experimental sepsis in mice, circulating adiponectin is reduced in mice with endotoxemic challenge compared with healthy control mice [47].

In the current study the values of adiponectin that were serially detected in all patients that reflects the actual different changes through the follow-up study (delta change or $\mathrm{dC}$ ) was highly significant with $\mathrm{P}$-value 0 meaning that adiponectin measurement could have a good prognostic value. These results are meeting with the study of (Uji et al., 2010) who found that the plasma adiponectin levels decreased at the early period of polymicrobial sepsis and early detection of low adiponectin may help in management of patients with sepsis as an assessment of the severity of septic process [48]. A recent study by Yamamoto and his colleagues found that adiponectin ratio could be the most useful predictor for postoperative infection in comparison with CRP [49].

We concluded in these studies that sepsis carries a high risk of multiorgan dysfunction syndrome and death in critically ill patients. PIRO score is an effective model for staging of sepsis and seems to be predictive of mortality Measuring serial procalcitonin levels may be the most useful, in order to understand the trend, identify the peak, and be able to identify resolution of sepsis. Early high lactate level is a predictor for poor prognosis of sepsis. Adiponectin is similar to procalcitonin in early detection of sepsis and can be used as a prognostic indicator with considering that adiponectin level could be affected by other metabolic disorders.

We recommend further studies with greater number of patients to ensure these results and other studies to assess the role of recombinant adiponectin in improving mortality in patients with sepsis.

\section{References}

[1] Skrupky L P, Kerby P W, Hotchkiss R S., 2011: Advances in the management of sepsis and the understanding of key immunologic defects. Anesthesiology; 115 (6): 1349- 1362.

[2] Le Gall JR, Alberti C, Brun Buisson C., 2004: [Epidemiology of infection and sepsis in intensive care unit patients]. Bull Acad Natl Med; 188(7):1115-25

[3] American College of Chest Physicians/Society of Critical Care Medicine Consensus Conference, 1992: definitions for sepsis and organ failure and guidelines for the use of innovative therapies in sepsis, Crit Care Med; 20:864-74.

[4] Levy MM, Fink MP, Marshall JC, Abraham E, Angus D, Cook D, Cohen J, Opal SM, Vincent JL, Ramsay G. SCCM/ESICM/ACCP/ATS/SIS: 2001 SCCM/ESICM/ ACCP/ ATS/ SIS, 2003: International Sepsis Definitions Conference. Crit Care Med; 31:1250-6.

[5] Annane D, Bellissant E, Cavaillon JM., 2005: Septic shock. Lancet; 365:63.

[6] Neviere R., 2012: Sepsis and the systemic inflammatory response syndrome: Definitions, epidemiology, and prognosis. Up to date, may, Parsons, PE (Ed).

[7] Hotchkiss RS, Karl IE., 2003: The pathophysiology and treatment of sepsis. N Engl J Med; 348:138-150.

[8] Russell JA., 2006: Management of Sepsis. N Engl J Med; 355:1699-1713.

[9] Perren A, Cerutti B, Lepori M, et al., 2008: Influence of steroids on procalcitonin and $\mathrm{C}$-reactive protein in patients with COPD and community-acquired pneumonia. Infection; 36: 163-6.

[10] Harbarth S, Holeckova K, Froidevaux C, Pittet D, Ricou B, Grau GE, Vadas L, Pugin J., 2001: Geneva Sepsis Network: Diagnostic value of procalcitonin, interleukin-6, and interleukin- 8 in critically ill patients admitted with suspected sepsis. Am J Respir Crit Care Med; 164:396-402.

[11] Ho KM, Towler SC. A., 2009: comparison of eosinopenia and $\mathrm{C}$-reactive protein as a marker of bloodstream infections in critically ill patients: a case-control study. Anaesth Intensive Care; 37:450-6.

[12] Guignant C, Voirin N, Venet F, et al., 2009: Assessment of pro-vasopressin and pro-adrenomedullin as predictors of 28-day mortality in septic shock patients. Intensive Care Med; 35:1859-67. 
[13] Seligman R, Papassotiriou J, Morgenthaler NG, et al., 2008: Prognostic value of midregional pro-atrial natriuretic peptide in ventilator-associated pneumonia. Intensive Care Med; 34:2084-91.

[14] Wu HP,Chen CK,Chung K,et al., 2009: Plasma transforming growth factor- $\beta 1$ level in patients with severe community-acquired pneumonia and association with disease severity. J Formos Med Assoc; 108: 20-7.

[15] Koch A, Gressner OA, Sanson E, et al. 2009: Serum resistin levels in critically ill patients are associated with inflammation, organ dysfunction and metabolism and may predict survival of non-septic patients. Crit Care; 13: 95.

[16] Davis BH and Bigelow NC, 2005: Comparison of neutrophil CD64 expression, manual myeloid immaturity counts, and automated hematology analyzer flags as indicators of infection or sepsis.Lab Hematol;11:137-47.

[17] Habib AM, Russo A, Zakariah AN, et al., 2005: Diagnosing Sepsis-Markers, Microarrays, and Multiplexes Intensive Care Med; 31(Suppl. 1):036 (abstr.).

[18] Marshall JC, Vincent JL, Fink MP, et al., 2003: Measures, markers, and mediators: toward a staging system for clinical sepsis. Crit Care Med; 31: 1560-67.

[19] Lobo SM, Lobo FR, Bota DP, et al., 2003: C-reactive protein levels correlate with mortality and organ failure in critically ill patients. Chest; 123: 2043-9.

[20] Meisner M, Tschaikowsky K, Palmaers T, Schmidt J., 1999: Comparison of procalcitonin (PCT) and C-reactive protein (CRP) plasma concentrations at different SOFA scores during the course of sepsis and MODS Crit Care; 3: 45-50.

[21] O'Grady NP, Barie PS, Bartlett JG, et al., 2008: Guidelines for evaluation of new fever in critically ill adult patients: 2008 update from the American College of Critical Care Medicine and the Infectious Diseases Society of America. Crit Care Med; 36: $1330-49$.

[22] Claeys R, Vinken S, Spapen H, et al., 2002: Plasma procalcitonin and $\mathrm{C}$-reactive protein in acute septic shock: clinical and biological correlates.Crit Care Med; 30: 757-62.

[23] Christ-Crain M, Stolz D, Bingisser R, et al., 2006: Procalcitonin guidance of antibiotic therapy in community.Am J Respir Crit Care Med; 174: 84-93.

[24] Gunnerson K J, Saul M, He S, and Kellum J A., 2006: Lactate versus non-lactate metabolic acidosis: a retrospective outcome evaluation of critically ill patients. Crit Care; 10(1): 22.

[25] Trzeciak S, Dellinger RP, Chansky ME, Arnold RC, Schorr C, Milcarek B, Hollenberg SM, Parrillo JE., 2007: Serum lactate as a predictor of mortality in patients with infection. Intensive Care Med; 33: 970-977.

[26] Bercault N, Boulain T, Kuteifan K. et al., 2004: Obesity-related excess mortality rate in an adult intensive care unit: A risk-adjusted matched cohort study. Crit Care Med; 32: 998-1003.

[27] Koerner A, Kratzsch J, Kiess W., 2005: Adipocytokines: leptin - the classical, resistin - the controversial, adiponectin - the promising, and more to come. Best Pract Res Clin Endocrinol Metab; 19: 525-546.
[28] Arita Y, Kihara S, Ouchi N. et al., 1999: Paradoxical decrease of an adipose-specific protein, adiponectin, in obesity. Biochem Biophys Res Commun; 257: 79-83.

[29] Gil-Campos, M., Canete, R., \& Gil, A., 2004: Adiponectin, the missing link in insulin resistance and obesity. Clinical Nutrition; 23, 963-974.

[30] Tilg H and Moschen AR., 2006: Adipocytokines: mediators linking adipose tissue, inflammation and immunity. Nat Rev Immunol; 6: 772-783.

[31] Kougias P, Chai H, Lin PH, Lumsden AB, Yao Q, Chen C., 2005: Adipocyte-derived cytokine resistin causes endothelial dysfunction of porcine coronary arteries. J Vasc Surg; 41:691-698.

[32] Oberholzer A, Oberholzer C, Moldawer L L., 2001: Sepsis syndromes: understanding the role of innate and acquired immunity. Shock; 16: 83-96.

[33] Teoh H, Quan A, Bang KW, Wang G, Lovren F, Vu V, Haitsma JJ, Szmitko PE, Al-Omran M, Wang CH, Gupta M, Peterson MD, Zhang H, Chan L, Freedman J, Sweeney G, Verma S., 2008: Adiponectin deficiency promotes endothelial activation and profoundly exacerbates sepsis-related mortality. Am J Physiol Endocrinol Metab; 295: 658-664.

[34] Retnakaran R, Zinman B, Connelly PW, Harris SB, Hanley AJ., 2006: Nontraditional cardiovascular risk factors in pediatric metabolic syndrome. J Pediatr; 148: 149-151.

[35] Iwashima Y, Katsuya T, Ishikawa K, Ouchi N, Ohishi M, Sugimoto $\mathrm{K}$ et al., 2004: Hypoadiponectinemia is an independent risk factor for hypertension. Hypertension; 43: 1318-1323.

[36] Rubulotta F, Marshall JC, Ramsay G, Nelson D, Levy M, Williams M., 2009: Predisposition, insult/infection, response, and organ dysfunction: A new model for staging severe sepsis. Crit Care Med; 37(4): 1329-35.

[37] Rello J, Rodriguez A, Lisboa T, Gallego M, Lujan M, Wunderink R., 2009: PIRO score for community-acquired pneumonia: a new prediction rule for assessment of severity in intensive care unit patients with community-acquired pneumonia. Crit Care Med; 37(2): 456-62.

[38] Furtado GH, Wiskirchen DE, Kuti JL, Nicolau DR., 2012: Performance of the PIRO score for predicting mortality in patients with ventilator-associated pneumonia. Anaesthesia \& Intensive Care; 40 (2), 285.

[39] Orlando D and Endaya, MD., 2012: Ventilator-Associated Pneumonia \& PIRO Score Philippine Heart Center; 16: 82-83.

[40] Póvoa P, Almeida E, Moreira P, et al., 1998: C-reactive protein as an indicator of sepsis Intensive Care Med; 24: 1052-6.

[41] Gokmen Z, Ozkiraz S, Kulaksizoglu S, Kilicdag H, Ozel D, Ecevit A, Tarcan A., 2013: Resistin-A Novel Feature in the Diagnosis of Sepsis in Premature Neonates. Am J Perinatol; 30(6) :513-7.

[42] Giamarellos-Bourboulis EJ, Mega A, Grecka P, et al., 2002: Procalcitonin: a marker to clearly differentiate systemic inflammatory response syndrome and sepsis in the critically ill patient? Intensive Care Med; 28: 1351-6.

[43] Jensen JU, Heslet L, Jensen TH, et al., 2006: Procalcitonin increase in early identification of critically ill patients at high risk of mortality. Crit Care Med; 34:2596-602. 
[44] Schuetz P., 2012: Role of Procalcitonin in Managing Adult Patients with Respiratory Tract Infections. Chest; 141:1063-1073.

[45] Bakker J and Jansen T C., 2007: Don't take vitals, take a lactate; Intensive Care Med.; 33(11): 1863-1865.

[46] Nguyen HB, Rivers EP, Knoblich BP, Jacobsen G, Muzzin A, Ressler JA, Tomlanovich M C., 2004: Early lactate clearance is associated with improved outcome in severe sepsis and septic shock. Crit Care Med.; 32: 1637-1642.

[47] Van Meurs M, Castro P, Shapiro NI, Lu S, Yano M, Maeda N, Funahashi T, Shimomura I, Zijlstra JG, Molema G, Parikh SM, Aird WC, Yano K., 2012: Adiponectin diminishes organ-specific microvascular endothelial cell activation associated with sepsis. Shock; 37(4): 392-8
[48] Uji Y, Yamamoto H, Maeda K, Tsuchihashi H, Akabori H, Shimizu T, Endo Y, Shimomura I, Tani T., 2010: Adiponectin deficiency promotes the production of inflammatory mediators while severely exacerbating hepatic injury in mice with polymicrobial sepsis. J Surg Res.; 161(2): 301-11.

[49] Yamamoto H, Maeda K, Uji Y, Tsuchihashi H, Mori T, Shimizu T, Endo Y, Kadota A, Miura K, Koga Y, Ito T, Tani T., 2013: Association between Reduction of Plasma Adiponectin Levels and Risk of Bacterial Infection after Gastric Cancer Surgery. Tani Surgery.PLoS One; 8(3):e56129 